Florida International University FIU Digital Commons

$11-7-2017$

\title{
Unsmiling Lips and Dull Eyes: A Study of Why We Continue to Read Jane Austen
}

Kareen Barakat

kbara004@fiu.edu

DOI: 10.25148 /etd.FIDC004008

Follow this and additional works at: https://digitalcommons.fiu.edu/etd

Part of the Literature in English, British Isles Commons

\section{Recommended Citation}

Barakat, Kareen, "Unsmiling Lips and Dull Eyes: A Study of Why We Continue to Read Jane Austen" (2017). FIU Electronic Theses and Dissertations. 3559.

https://digitalcommons.fiu.edu/etd/3559

This work is brought to you for free and open access by the University Graduate School at FIU Digital Commons. It has been accepted for inclusion in FIU Electronic Theses and Dissertations by an authorized administrator of FIU Digital Commons. For more information, please contact dcc@fiu.edu. 
FLORIDA INTERNATIONAL UNIVERSITY

Miami, Florida

UNSMILING LIPS AND DULL EYES:

A STUDY OF WHY WE CONTINUE TO READ JANE AUSTEN

A thesis submitted in partial fulfillment of

the requirements for the degree of

MASTER OF ARTS

in

ENGLISH

by

Kareen Barakat

2017 
To: $\quad$ Dean Michael R. Heithaus

College of Arts, Sciences and Education

This thesis, written by Kareen Barakat, and entitled Unsmiling Lips and Dull Eyes: A Study of Why We Continue To Read Jane Austen, having been approved in respect to style and intellectual content, is referred to you in judgment.

We have read this thesis and recommend that it be approved.

Michael Gillespie

Maneck Daruwala

Jason Pearl, Major Professor

Date of Defense: November 7, 2017

The thesis of Kareen Barakat is approved.

Dean Michael R. Heithaus

College of Arts, Sciences and Education

Andres G. Gil

Vice President for Research and Economic Development and Dean of the University Graduate School

Florida International University, 2017 


\title{
ABSTRACT OF THE THESIS
}

UNSMILING LIPS AND DULL EYES:

\section{A STUDY OF WHY WE CONTINUE TO READ JANE AUSTEN}

by

\author{
Kareen Barakat
}

Florida International University, 2017

Miami, Florida

\section{Professor Jason Pearl, Major Professor}

The purpose of this thesis is to take a closer look at Jane Austen's work and understand the importance of it in both the academic and cultural sphere. With a specific focus on Pride and Prejudice, this research starts with a focus on feminist readings of the novel. Primarily, this research looks at the novel with a feminist lens in order to better understand the female characters and their involvement in the marriage plot. Secondarily, the research goes on to look at the cultural impact of Pride and Prejudice and attempts to understand the ways in which this novel re-appears in different adaptations. Finally, the research suggests that there should be a new way of reading Austen that better fits contemporary society. Despite how far removed Jane Austen's world may seem, her work remains important and worth studying. This thesis argues in favor of the appreciation of Jane Austen's work both academically and culturally. 


\section{TABLE OF CONTENTS}

CHAPTER

PAGE

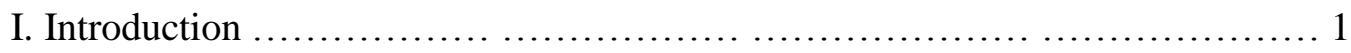

II. Unsmiling Lips.................................................. 9

A Woman in Regency England................................... 12

Why Read Austen?................................................. 21

III. Dull Eyes .............................................................. 24

The Adaptation.................................................... 29

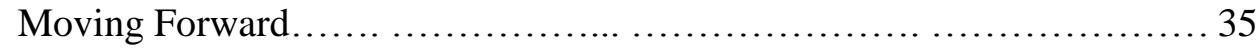

IV. Conclusion........................................................... 39

References............................................................ 42 


\section{Introduction}

"In the gallery there were many family portraits, but they could have little to fix the attention of a stranger. Elizabeth walked on in quest of the only face whose features would be known to her. At last it arrested her..." - Jane Austen, Pride and Prejudice

Elizabeth Bennet walks through the halls of Pemberley, feeling anxiety about being in a massively impressive home that easily could have been hers. The great and important Mr. Darcy asked Elizabeth to be his wife, and Elizabeth stubbornly declines because she had her own reasons to stay away from him. A few months later, as she visits Pemberley, Elizabeth cannot help but feel a tinge of regret at her decision. Every room of the house causes her to consider and reconsider her past decision, sending Elizabeth into a whirlwind of discomfort. It is only when she finds Mr. Darcy's portrait in the gallery that she suddenly feels a sense of comfort. Elizabeth knows Mr. Darcy, she knows the man in the portrait. The look in the picture makes her think of the look he would sometimes give her, and it warms her to the subject of the painting. It is at this moment that everything changes, that Elizabeth finally allows herself to open up to the possibility of being Mr. Darcy's wife. With the aid of a picture, Elizabeth can finally see who Mr. Darcy is. ${ }^{1}$

To think of a picture as a source of bringing people together almost seems absurd. A picture only bears the likeness of an individual, and should never be confused with the actual, physical being. Still, the plot of Pride and Prejudice very much depends on Mr.

\footnotetext{
${ }^{1}$ A retelling of the scene on page 244 of Pride and Prejudice
} 
Darcy's portrait and, clearly, Jane Austen must have seen some value in a picture. It almost seems ironic that Austen writes out this scene because over two hundred years after the publication of Pride and Prejudice, in September of 2017, a $£ 10$ banknote enters circulation in England with Jane Austen's face on it. The fact that Jane Austen's face has been considered as worthy to be printed on British currency speaks to her ongoing popularity and permanent place in popular culture. Jane Austen's face on the banknote, however, does not look like her face at all. Much criticism of the banknote points to the fact that the Bank of England has chosen an inaccurate portrait of the authoress. Sophie Christie reports in The Telegraph that the portrait printed on the banknote, "shows her noticeably prettier and less drawn than she appears in the only contemporary painting ${ }^{2}$ of her which exists." Jane Austen has been drawn to look more attractive, and this is nothing new. The likeness of Jane Austen has been so tampered with and so evolved that the portrait itself should have a study of its own. However, in this case, it is the uproar surrounding this banknote that says so much about public fascination with Jane Austen. The public does not want a pretty picture of their favorite author; they want (what they believe to be) a "real" picture of Jane Austen. After all, so many readers have grown up with her, made her a permanent part of their lives, watched the films and read the spinoffs. After all this time and all this attachment, no one wants to see a "new" Jane Austen. The fascination with this woman's portrait says a lot and is very representative of Jane Austen studies in general. Austen fans are passionate about the novels, and anything surrounding them. A sudden change could be devastating to the Jane Austen fan. No one

\footnotetext{
${ }^{2}$ Christie refers to the painting drawn by Austen's sister Cassandra Austen, which is now on display at the National Gallery in London
} 
wants to see an adaptation where Darcy is un-noble or Elizabeth timid. No one wants to consider that the person closest to Jane Austen, her sister Cassandra, may very well have been a horrible artist. If the closest person to Jane drew the picture, then this picture must be accepted as the true image of the beloved Jane.

Jane Austen is one of the world's most celebrated and loved authors. Her work has been read over and over since publication in the 1800's. Somehow, Austen's six little novels have made such an impact and continue to inspire countless generations to reimagine her work and create all kinds of adaptations. Jane Austen changes with time and it is this staying power that is so remarkable. How does one author remain relevant and important not simply to academic audiences, but popular culture as well? The question of Austen's relevance in both the academic and cultural sphere is the aim of this project. In so many cases, Austen's work and influence appear in both areas of society and show no signs of going away. It has become important to outline the ways in which Austen continues to make an appearance and also to understand and acknowledge new ways of engaging with her work.

Jane Austen's novels have always been well-liked but over the years Jane Austen as a person has become something of an icon. The fact that a woman could write such well-loved novels in the time period that she did is such a powerful and inspiring concept. Perhaps today, more than ever before, readers love to think about Austen writing her novels as much as they look at the actual stories. This is important because the fascination has moved outside of the novel and even more towards what Austen was thinking when she created her work. More specifically, did Austen write the way she did out of frustration with her own position as a woman? The reader, of course, will never 
know one way or anther, but to begin to think about the novels as more than just love stories is important.

In the critical article "Imagining Jane Austen," Anna Quindlen describes her own fascination with Jane Austen. Quindlen writes,

For me the issue of power in the fiction of Jane Austen was not simply contained in what she wrote. It was contained in the very fact that she existed, that there had been in the world an ordinary girl, reared in a large family, sent away unhappily for a time to a girl's school, bosom friends with a beloved sister, not part of a glittering salon, not blessed with grand lineage, not living in London, not educated at Cambridge, an ordinary girl who became an ordinary woman who became immortal by the pushing of pen across paper. (15)

Jane Austen did something special, especially when considering how her work has been inspiring to so many people. She did not have special treatment or a special education, she simply wrote about things she knew and things she observed and she subsequently changed the role of women in literature forever.

Jane Austen slyly writes in Persuasion, "men have had every advantage of us in telling their own story. Education has been theirs in so much higher a degree; the pen has been in their hands. I will not allow books to prove anything” (221). This part of Persuasion has become one of Austen's most famous quotes. Most classic literature, or at least what has always been deemed important, comes from male authors. Jane Austen stands out in this list of classics because of her status as a woman. As a woman, she has found a way to hold a pen in her hand and tell the story she knows, the story of women. Austen's heroines do not take long epic journeys like Odysseus or fight for survival on a 
deserted island like Robinson Crusoe. Austen's novels do not venture much further than travel between a small country village and the city of London, and the heroines would never step out without a chaperone. Austen knows that men could tell stories of their own and have the advantage of telling stories with all kinds of embellishments, but once she gets her hands on a pen she chooses to tell a story much closer to reality. Women have always been kept in the parlor, far away from any adventure, and so it is this that Austen chooses to write about. However, when Austen does so, one may argue that Elizabeth Bennet becomes something of a hero that challenges any of the male literary figures that came before her, and with this irony, Austen writes about books, men and advantage in Persuasion.

Jane Austen's novels have become a part of classic literature and stand side by side with the writing of other men because her novels truly are excellent. They have withstood the test of time because people absolutely love to read them. Austen did not gain fame merely because her life was fascinating or she was connected to other famous writers. In fact, little is known about the woman behind these novels, and most of what people claim to know about her arises out of pure assumption. Of the few scraps of hard evidence regarding Jane Austen, some of it comes from her writing and the rest from the previously mentioned, old sketch drawn by her sister Cassandra.

The picture is old and faded, with only the face standing out more clearly than the rest of her body, but it is widely believed and accepted to be the true likeness of the author. In this image a woman not quite young but certainly not old, sits with her head turned to the side. She does not look directly at the painter, or her audience, and instead leans away deep in thought. Brown shining curls peep out from under her bonnet 
because, of course, the woman who created Lizzie Bennet's character must have dark hair. Her curls fall evenly and strategically. Jane Austen does not pose for a picture in the way one may expect. No hint of a smile plays at her lips. Her arms are crossed over and it seems forced and unnatural. Austen's eyes do not create excitement or suggest a hidden knowledge. They almost seem dull as they look away from the painter. Austen's eyes reveal nothing. The portrait is puzzling, to say the least. Viewers cannot look at it and find out anything about the beloved Jane Austen. This does not seem like the individual who wrote the humorous interactions between Mr. and Mrs. Bennett, or who created beautiful stories that many generations have cherished. More importantly, this does not seem like the Jane Austen who broke social conventions and wrote widely read novels despite her status as a woman in Regency Era England. Instead, it looks like a bland painting of a plain woman with nothing interesting and certainly not worth noting. If this portrait had never been associated with Jane Austen, it may have never been worth noting.

However, it has been cherished and preserved. It has been placed in a gallery and framed. This is Jane Austen, and therefore we must pay attention to this portrait. The amount of observation paid to this unremarkable portrait comes from the public obsession with Jane Austen. All things Austen have been held in high regard because readers have such limited information about her, and so anything they can find must be meditated upon and thought about. From an academic point of view, the portrait is only as interesting as the ways in which it has been changed and re-imagined, and this directly points to the cultural perspective, which wants Austen to always evolve with the times. Clearly, the academic and cultural must be thought of in conjunction because they each 
complement and inform the other. The Unsmiling Lips of the portrait almost seem to represent the academic side of Austen's following, which speaks to the more serious readings of her work and the power academics hold when dictating exactly how to read and understand Austen. On the other hand, the Dull Eyes represent the more cultural side of Austen and the ways in which many readers simply observe Austen, either through adaptations or other cultural avenues, without always thinking critically about the best way to engage with her work. This study has been split into Unsmiling Lips and Dull Eyes in order to understand Austen's relevance both academically and culturally, and will attempt to prove that Austen's work deserves all the praise it receives because it changes with its readers.

The eyes and lips of any face communicate what you want to say to the world. In Pride and Prejudice, and any of Austen's other works, readers can recall countless moments of characters looking at one another and how sometimes these looks can be even more telling than what they ever actually say. Communication can only happen when the eyes and lips come together, and in the same way, studying Austen should always combine the academic and cultural. 


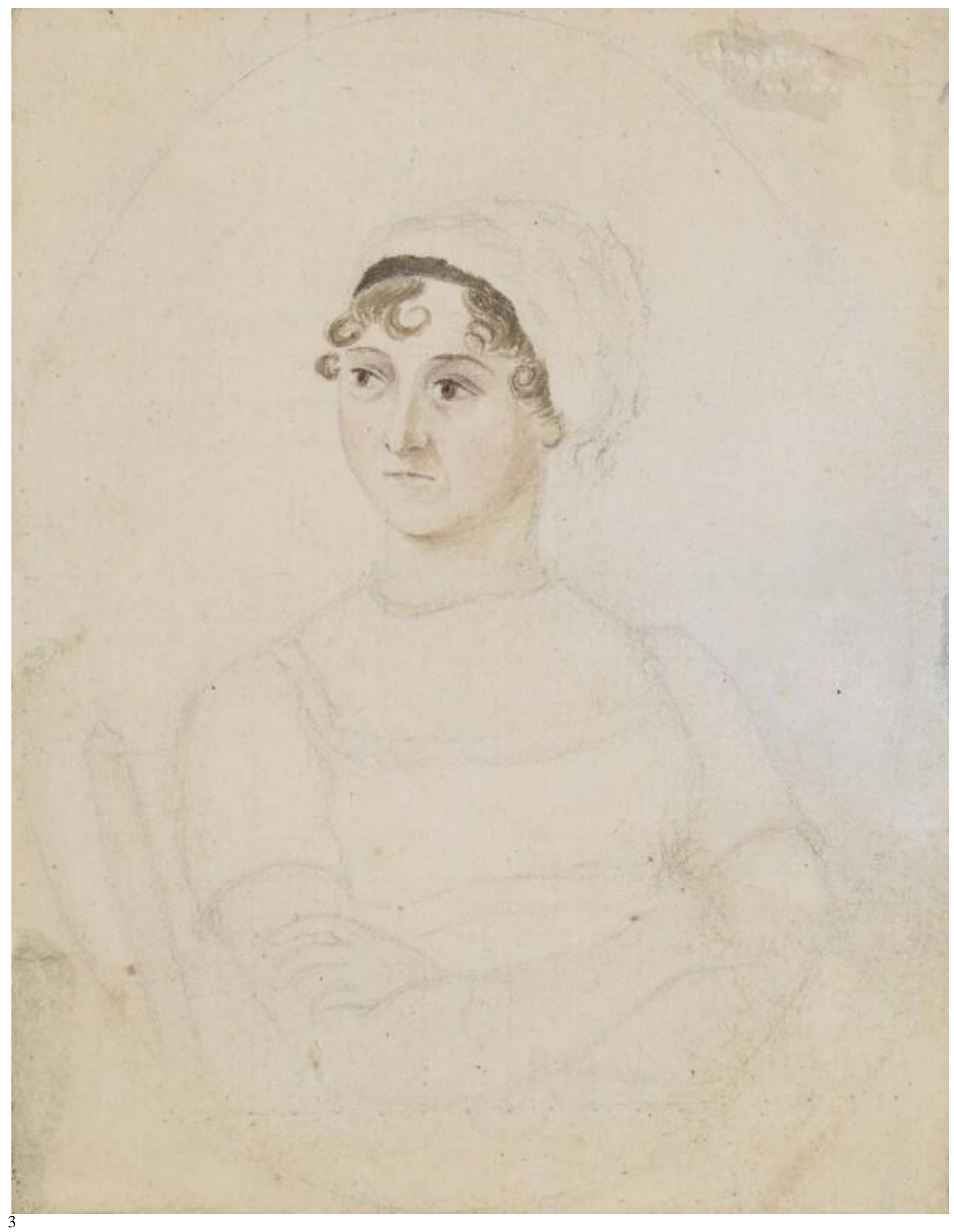

${ }^{3}$ Drawing by Cassandra Austen, National Portrait Gallery, London 


\section{Unsmiling Lips}

"Elizabeth had never been more at a loss to make her feelings appear what they were not. It was necessary to laugh when she would have rather cried." - Jane Austen, Pride and Prejudice

As Elizabeth sits in her father's study she must listen to him read Mr. Collins' letter warning against a union between Elizabeth and Mr. Darcy. Her father laughs at the very idea and expects his daughter to find the letter just as amusing. Elizabeth must perform and laugh along in order to hide her true feelings. Very rarely do the characters in Austen's work get the opportunity to truly say what they mean, or to fully express themselves without limits. Elizabeth wants to cry, but forces herself to laugh in order to mask her true feelings. Her lips reveal nothing, and press tightly together on the subject that fills her head and heart.

In many ways, Elizabeth's situation almost matches that of the author who wrote this scene. Not much is known about Jane Austen, of course, but the portrait shows a woman unsmiling and almost unhappy. Much like Elizabeth at this moment, Austen's lips remain closed and silent. The author who wrote words so loved and cherished seems to have nothing to say at all in the picture. Austen's Unsmiling Lips not only point to the deafening silence of many of Austen's characters, but also to the situation many academics face when studying Jane Austen. Although it may seem that scholars have the benefit of possibly publishing great work about Austen's novels, there remains a sort of struggle to actually have that work widely received and understood. It can be difficult for 
certain academics to accept Austen because of the content of her novels and the argument that Austen culture can either be silly or regressive. On the other hand, Austen academics do not always manage to cross over and make a connection with more casual readers. For this reason, the way in which we study Austen is extremely important because it has to appeal to so many different audiences. With Unsmiling Lips does the academic world discuss Jane Austen's work.

Jane Austen's work points to a recurring issue in each and every one of her novels. The female characters always face the same problem of trying to enter the inevitable state of marriage without compromising their own happiness. These heroines desire a meaningful attachment and not merely an arranged transaction. The novels Austen writes are filled with unhappy marriages but readers usually assume that the marriage of the heroines will be the happiest and be different from the couples that surround them. This assumption, unfortunately, may be too easily made. Although most people think of Austen's novels as simple and romantic love stories, many readers overlook the formulaic nature of these romance novels. They always follow a pattern of bringing the main couple together at the very end of the story, usually after much confusion and a failure to recognize one another as a love interest. One may go as far as to say that the endings seem somewhat farcical and patched up, with the heroines of each novel giving in to the status quo and yielding to the inevitable, marriage.

Each and every Austen novel has its own unique heroine with different situations in life. Very rarely do the young women in these novels pine for a romantic partner more than they wish for stability and daily comfort. Fanny Price of Mansfield Park struggles to find her voice in a home filled with her cousins and friends who have totally clashing 
personalities that differ from her own calm manner, while young Emma has no problem offering her opinion and only hopes to find entertainment within the confines of her small town. To go down the list of each Austen novel would not only show that each lead female character has her own unique share of struggles, but very rarely does their struggle include an overwhelming desire to get married. The heroines do not want love and romance as much as they want to be comfortable in their situations, and they have to work with the very limited tools available to them as women.

The only novel that places such a blatant emphasis on the necessity of marriage is probably Austen's most famous work, Pride and Prejudice. In this novel, the reader can guess from the wildly popular opening line that the focus will be on marriage. As the story goes on, Austen does something interesting by not only showing the marriage of one or two couples, but at least four different pairings happen by the end of the story and the reader gets to look at totally different types of relationships and totally different levels of happiness. Moreover, in this novel, more than any other Austen novel, the reader understands different pressures from the point of view of these single young women, and what exactly leads them to marriage. In most cases, love is not the most determining factor in finding a suitor. For this reason, the focus of my thesis will be on Pride and Prejudice and the female characters in it. What leads these women to marriage, and how do their unique situations land them in the sort of unions they find themselves in? More importantly, how does a feminist reading of Pride and Prejudice enrich this understanding of the female characters and simultaneously enrich an understanding of our culture's attachment to Jane Austen's work? These are the questions that drive the research of this project. 
Without a doubt, each of the unions in Pride and Prejudice are wildly different, and Austen makes it clear that the happiness of a character like Lydia Bennet does not match the happiness of her elder sisters. A feminist reading of the novel will enrich the understanding of each of these women and their subsequent marriages, and eventually reveal the reasons Austen would include such differences with each character. Unsmiling Lips will then transition to more of a questioning of why readers continue to interact with Jane Austen despite the obvious removal from modern feminism. Readers may laugh when they read Austen's work and they may find the novels lighthearted and sweet. However, if Austen wrote these with Unsmiling Lips, it is the reader's responsibility to investigate this work further and understand the underlying issues Austen quietly sheds light on. Pride and Prejudice must be much more than what we immediately see on the surface, and reading must go beyond the "love story."

\section{A Woman in Regency England}

"A woman must have a thorough knowledge of music, singing, drawing, dancing, and the modern languages, to deserve the word; and besides all this, she must possess a certain something in her air and manner of walking, the tone of her voice, her address and expressions, or the word will be but half deserved." - Jane Austen, Pride and Prejudice

As Caroline Bingley parades around the parlor of Netherfield estate, she lists off all the skills a woman must have in order to be truly deemed "accomplished." She does so in order to recommend herself to Mr. Darcy and show that her competitor, Elizabeth 
Bennet, could hardly boast of mastering even half of these skills. The scene shows a little exchange between Elizabeth and Caroline when finally Elizabeth exclaims there cannot possibly be such a perfectly accomplished woman. Caroline Bingley shoots back, "Are you so severe upon your own sex, as to doubt the possibility of all this?" (41). At this moment, the reader takes a step back and has to wonder who in this situation is being "severe." Caroline and Elizabeth have very different ideas about what it means to be a woman, and with Caroline so clearly painted as an unlikeable character, Austen nudges her reader to side with Elizabeth. It almost feels like Austen pokes fun at social expectations and conventions without ever saying anything at all.

It may be difficult to understand the women in Austen's novels without first understanding their differences from the women in contemporary society. These characters have absolutely no chance at financial independence. If a woman could not work she could never truly make decisions for herself. If women like the Bennet sisters have their father's estate entailed ${ }^{4}$, they must marry to ensure their own safety and comfort. With so much pressure surrounding the marriage of these five sisters, love can hardly take center stage in the way one might expect from a so-called "romance" novel. With so little to depend on, these characters present themselves as ornaments to society, at least to the best of their abilities, in order to secure their futures.

The women in these novels stand at an extreme disadvantage when placed next to the leading male characters, Mr. Darcy and Mr. Bingley. These two men may travel as they please and have full control over their own income. Because they have each

\footnotetext{
${ }^{4}$ On the entailment of Longbourn estate, “Mr. Bennet's property consisted almost entirely in an estate of two thousand a year, which, unfortunately for his daughters, was entailed, in default of heirs male, on a distant relation" (29).
} 
inherited a fortune from their respective fathers, these men also do not have to work. They may literally do whatever they please and hardly have to exert much effort to earn respect from the general public. Women like the Miss Bennets, on the other hand, can do little more than stay at home and their business in life is to enrich their minds with "feminine" skills, such as painting and playing the piano, until they find themselves marriageable men. The education of a young woman in Regency England operated within very specific and suffocating confines

Jane Austen does not show alternatives of young women who decide to do something with their lives, and choose not to depend on marriage for security because this could rarely happen. The only form of rebellion a reader may find is in Elizabeth Bennet's slight criticism of the accomplished woman. Small as it may be, the reader finds that Elizabeth does not see the importance in things that society has dictated women must do. Each of the Bennet sisters have been left free to study things they enjoy, and Elizabeth says herself that "those who chose to be idle certainly might" (164). The education of these girls varies, and perhaps this inconsistency points to a larger statement about the education of young women. It does not necessarily matter that a young woman can paint or sing because in the end it is not these things that help them move forward with their lives. Accomplished women are not really any better off than the Bennet sisters because the education of a young woman does not really change the course of their lives. They all must attempt to marry well in the end, or risk being a burden to their parents.

In the 1973 critical piece titled, "Jane Austen and the Feminist Tradition," Lloyd W. Brown touches upon the education of women in the Austen novels and the issues this type of education brings. Brown writes, "But it is in Pride and Prejudice that we are most 
aware of a conscious and extended preoccupation with conflicting concepts of education for women - and the relationship between that education and marriage. The conflicts are explicit in the differences between the Bennet sisters," and in the failure of their parents to play stronger roles as mother and father to these girls (328). Without a doubt, the Bennet girls each have starkly different personalities, but the difference in their education says a lot about why they do not resemble one another. Education, in this case, relates to the feminine skills and also general care and attention from the parents. The novel clearly sets apart the two eldest daughters from the three younger ones. The narrative describes the eldest, Jane, as a sweet and mild tempered girl, while the youngest, Lydia, proves herself to be something of a wild child who makes decisions with potentially horrible consequences for the rest of the family unit. Although the skills these two sisters possess is never explicitly listed off, the reader is made to understand that the two elder sisters stand in total contrast to the younger ones with their understanding much more refined ${ }^{5}$.

Brown goes on to say, "Mrs. Bennet is the conventionally educated woman whose sex-oriented view of women's roles limits her ambitions in her own marriage, and eventually, in the marriages of her daughters. And her narrowly female expectations of marriage as a self-justifying end are matched by and implicitly attributed to the male's proprietary view of women as possessions" (337). Mrs. Bennet understands the role of women as nothing that could ever go beyond the realm of marriage because this is as far as she witnessed in her own experience. Clearly, the limited education of young women in this era works to keep women stagnant as nothing more than the wives of men. To be

\footnotetext{
${ }^{5} \mathrm{Mr}$. Bennet says to Elizabeth, "Wherever you and Jane are known, you must be respected and valued; and you will not appear to less advantage for having a couple of or may I say three - very silly sisters" (226).
} 
sure, Mrs. Bennet's character serves as the perfect example of a person who perpetuates this cycle, but a closer analysis of her character may prove Mrs. Bennet to be much less a silly character than readers commonly assume.

Ill-equipped with a deficient education and a husband who did know how to properly budget his finances, Mrs. Bennet finds herself stuck in a difficult situation with five daughters she will potentially need to support if her husband passes away. Mr. Bennet offers no solutions or recommendations for his family and instead opts to shut himself away in his study and not worry himself with the complaints of his wife. Understanding that women have no other option but to marry, Mrs. Bennet makes it her utmost goal to marry off each of her daughters in order to make sure they do not want for anything. When Mr. Collins makes an offer of marriage to Elizabeth and she refuses him, Mrs. Bennet does not hold back on expressing her anxieties to her daughter. She says, "I am sure I do not know who is to maintain you when your father is dead. I shall not be able to keep you — and so I warn you. I have done with you from this very day... I have no pleasure in talking to undutiful children" (113). It can be easy to laugh off this scene and view Mrs. Bennet's outburst as overly dramatic. However, Mrs. Bennet understands the importance of her daughters finding husbands who will be able to support them and she carries the weight of this anxiety completely on her own. Elizabeth herself does not truly understand her own situation in life since she so quickly and surely turns down Mr. Collins. She either does not realize how little her "education" will help her if her father passes away, or she has a huge amount of confidence that a better offer will come along. Either way, Mrs. Bennet is no fool for worrying over her family's future because she realizes how little she can do for her family as a woman. Mrs. Bennet may be stuck in the 
vicious system of keeping women in the home, but she sees that as the only way of survival. She pushes her daughters to get married because it is the only solution that she knows will keep them safe.

The only other character that seems to fully understand the disadvantages of being an unmarried woman is probably Charlotte Lucas. Although Elizabeth's best friend, Charlotte has a totally different view of marriage. Charlotte's acceptance to enter an engagement with Mr. Collins may seem foolish and desperate to some readers, or at the very least a shock, but she displays signs of her practicality early on in the novel. At the Netherfield ball, Mr. Darcy asks Elizabeth to dance with him and when he approaches, "Charlotte could not help cautioning [Elizabeth], in a whisper, not to be a simpleton, and allow her fancy for Wickham to make her appear unpleasant in the eyes of a man ten times his consequence" (91). Charlotte clearly does not think with a romantic mind, and she understands the workings of society and knows that attention from a man like Darcy would be much more beneficial to her friend than any loyalty she shows to Mr. Wickham. Her realistic way of thinking may be an important characteristic for a woman's survival in this patriarchal society.

Most discussions and adaptations of Pride and Prejudice make the mistake of misrepresenting Charlotte Lucas. She is usually the forgotten character, and if ever remembered, it is for her stupidity in marrying Mr. Collins. In the academic article, "Charlotte and Elizabeth: Multiple Modernities in Jane Austen's Pride and Prejudice," Melina Moe's discussion of Charlotte presents her as a much more important character for the narrative. Moe writes, "Charlotte Lucas does not play a large role in the formidable body of Austen scholarship. When she is involved, it is usually as a 
humorous, slightly pathetic, and anachronistic minor character" (1075-6). Charlotte's settling for Mr. Collins may seem "pathetic" but she understands that it is a decision that will help her entire family. Her brothers and sisters would all benefit from Charlotte's marriage ${ }^{6}$ and she would have met her goal of marrying, especially since she did not "[think] highly of either men or matrimony" (122). Charlotte has finally secured her place in the world and this is quite an accomplishment.

When Charlotte must tell her best friend about her engagement, they have a conversation that, although brief $^{7}$, says a lot about marriage in an oppressive society. Austen's work may be regarded as a romantic novel, but Charlotte's marriage sheds light on attachments that happen out of convenience. What Elizabeth wants in a partner is not something all women can afford to wait for. Melina writes about the interaction between Charlotte and Elizabeth and says

By reading Charlotte's and Elizabeth's disagreement as a serious debate, rather than a pro forma narrative of modernity's development, we can see that the subjective orientation toward freedom, progress, and self-growth that is so clearly formative for Elizabeth Bennet is not taken for granted by Austen as normative for all women. Charlotte Lucas marries Mr. Collins and expects to live a fulfilling life with him. Conscious of Elizabeth's differing views, Charlotte anticipates

\footnotetext{
${ }^{6}$ On Charlotte's family benefiting from her upcoming marriage. "The whole family in short were properly overjoyed on the occasion. The younger girls formed hopes of coming out a year or two sooner than they might otherwise have done; and the boys were relieved from their apprehension of Charlotte's dying an old maid" (122).

${ }^{7}$ Charlotte tells Elizabeth about her decision to marry Mr. Collins, "I am not a romantic, you know I never was. I ask only for a comfortable home" (125). Elizabeth has a hard time understanding her friend's point of view.
} 
being hurt by her friend's disapprobation, but makes no excuses for her marriage as an act of martyrdom or of submission to crushing necessity. (1098)

Not all women could afford to be romantic and Charlotte takes this opportunity because to be married will always offer her more security than to be unmarried. Elizabeth's own failure to understand her friend's situation shows how little she comprehends her own danger as a single young woman. It is Elizabeth's ignorance that keeps her so confident, as opposed to showing any sign of anxiety, throughout the rest of the novel.

The family unit, in many cases, does not provide security for the young woman. The Misses Bennet cannot hope to live in Longbourn forever, or view it as a place they may always return to if things in life take an unexpected turn. Aside from this being an impossibility because of her family's financial situation, the text also says, "[h]ad Elizabeth's opinion been all drawn from her own family, she could not have formed a very pleasing picture of conjugal felicity or domestic comfort" (231). Girls like the Miss Bennets must look outward for security. They must look to their future husbands in order to find their position in society guaranteed. With Charlotte's own future settled, Lydia becomes the next female character to get married. Going against social conventions, Lydia decides to run away with Mr. Wickham and after they are found, forced to get married. Lydia has no regard for what her actions mean for her four unmarried sisters and seems quite happy with herself for having been the first Bennet sister to get married. Everyone in the family suffers, but Elizabeth's point of view shows her own deep embarrassment and shame at having such a family. When Elizabeth is forced to tell Mr. Darcy about Lydia and Wickham, the novel reads, "Elizabeth soon observed and instantly understood it. Her power was sinking; every thing must sink under such a proof of family 
weakness, such an assurance of the deepest disgrace" (269). Elizabeth not only fears that Mr. Darcy will no longer love her, but more importantly, she understands the stigma of having a sister do something considered so immoral. Elizabeth becomes hyper-aware of her family's situation and fears the social repercussions of such a scandal. For the first time in the narrative, more than halfway through the novel, the reader can sense Elizabeth's anxiety.

Elizabeth eventually finds a way to distance herself from her family and their multiple embarrassments when she and Mr. Darcy finally do get together at the end of the story. Their engagement is described as an anxious time, when Elizabeth must constantly hide Darcy from her more embarrassing family members and "she looked forward with delight to the time when they should be removed from society so little pleasing to either" (371). She would become the mistress of Pemberley and live far away from her family. The original family, once again, is not a safe place for young women.

In the article "Exit Strategies: Jane Austen, Marriage and Familial Escape," Daniele Barkley discusses the marriages in Austen novels and how the more successful unions differ greatly from the family these characters come from. Barkley writes, "I don't believe, however, that in Austen's novels conjugal families merely represent continuations of the stability granted by families of origin. Austen's successful marriages pointedly defy the structures of families of origin, and when heroines strive to replicate their childhood families via endogamous marriages, they encounter multiple sites of disappointment" (215). The marriage not only becomes a way to escape the home, but it also allows the characters to stop old and unsatisfying patterns of family life. Elizabeth marries someone totally new to the Bennet family and she manages to move away and 
start her own, new family circle with people she loves like the Bingleys and the Gardiners. By leaving Longbourn and all its defects behind her, Elizabeth has managed to create a new life that the reader can safely assume is happy and healthy. Moreover, Elizabeth moves up in society and no longer has to live with the embarrassment that comes with being part of a lower social class. People like Caroline Bingley can no longer look down on Elizabeth. Lydia and Wickham, on the other hand, mirror her parents by "always spending more than they ought," and their affection for one another falling apart not too long after getting married (374). Lydia may have gotten married first, but she did not truly escape the home like Elizabeth manages to. Lydia simply repeats patterns she saw in her own home and does not move ahead in society. Elizabeth, on the other hand, moves up in society and truly experiences a whole new way of living.

\section{Why Read Austen?}

"But people themselves alter so much, that there is something new to be observed in them for ever." - Jane Austen, Pride and Prejudice

When Mr. Darcy ridicules Elizabeth's study of character as being far too narrow and limited in the country as compared to the city, Elizabeth says that people change so much that she hardly feels the need to find new subjects worth studying. This moment almost points to the Jane Austen reader, who looks to the same six novels over and over again with the same characters, but always finds something new to enjoy in their reading. In one reading Elizabeth Bennet can seem the strong and unafraid female, while in 
another her lack of power and options is apparent. Jane Austen's characters change with every reading. For this reason, despite all the criticisms of Austen's novels, her work remains popular.

Without a doubt, the time and space Austen writes about can seem so far removed from contemporary society that it can be easy to question the benefit in reading Jane Austen at all. After all, women no longer have to get married as a survival tactic and there's no apparent reason to glorify fictional men like Mr. Darcy. When reading Austen's fiction in a literal sense, as strange and patched up "love stories," it can even be considered harmful and regressive to everything feminism has worked for thus far. After looking at Austen's work with a feminist perspective, one may begin to question why we read Austen at all? To throw Jane Austen and her work out the window, or at least attempt to, is hardly useful. As far as the relationship between feminism and Jane Austen's literature, it would be a great loss to do away with some of the most wildly popular, female-written work in the English language. Moreover, many readers have begun to understand Austen's work as much more than what the plot seems at the surface. One of the most important texts to help lead readers to this alternative way of interpreting Austen being the 1979 text, The Madwoman in the Attic ${ }^{8}$.

Sandra Gilbert and Susan Gubar dedicate a considerable amount of their text to discussing Jane Austen as an author and the content of her novels. Rather than criticize Jane Austen for the subject matter of her novels, namely the marriage plot, they recognize the power in Jane Austen writing about what she knows, and what is available to women

\footnotetext{
${ }^{8}$ One of the seminal texts on feminism and literature. Published in 1979, Gilbert and Gubar focus on Victorian female writers such as the Brontës and Elizabeth Gaskell, in addition to Jane Austen.
} 
in her situation. They write about the intelligence of Jane Austen as a writer and how she manages to succeed as an author despite this being a realm usually inhabited by men. They write,

Austen's culture is not a destroyed rubble around her corpse. On the contrary, it is a healthy and powerful architecture which she must learn to inhabit. Far from looking under razed buildings or (even more radically) razing buildings herself, Austen admits the limits and discomforts of the paternal roof, but learns to live beneath it. As we have seen, however, she begins by laughing at its construction, pointing out exactly how much of that construction actually depends on the subjugation of women. (121)

Gilbert and Gubar assume that as a writer, Austen understands the issues for women like herself in a patriarchal society and rather than completely shake up the world she knows, Austen slyly criticizes it through the subject matter of her work. She writes solely about single young women who have their own set of struggles, which they only seem to know how to solve by getting married. Marriage in these novels, however, only shows up as unsuccessful unions full of bickering, like that of Mr. and Mrs. Bennet, or they do not show up at all. The reader can only make assumptions about the marriages that happen at the very last pages of each of Austen's novels.

Every single Austen novel ends with the main characters getting together and presumably getting married. Very little is known about the type of union between characters like Emma and Mr. Knightley or Fanny Price and Edmund Bertram. The readers must decide for themselves what the marriage will look like, or at the very least be satisfied with a supposedly happy ending. The only Austen novel that spends just a 
little bit more time discussing the marriage between the main characters would be Pride and Prejudice. The novel ends with a final, short chapter that offers very quick descriptions of Lydia and Wickham's failing marriage and Elizabeth and Darcy's happiness at Pemberley. The ending teases out certain details about the future lives of these couples, but never really focuses on any one thing to make a clear picture of their domestic lives. The very last sentence of the novel discusses the Gardiners and praises them as the couple that brought Elizabeth and Mr. Darcy together. This seems like a strange choice to finish the novel with. The entire ending is odd and rushed, much like the marriage plot itself. This means the reader can still take many liberties and imagine thousands of possibilities that could have happened to Elizabeth after the honeymoon phase was over. In other words, the marriage at the end of Austen novels is presented in a way that is supposed to seem happy and satisfying to the reader, but so little is known about how the marriage turns out so it may be just as valid to think of an alternative. Elizabeth Bennet does not necessarily have to have a happy ending.

The marriage plot has always been a major criticism of Austen's work. Many other writers of Austen's time have focused on female characters, but no other writer has so blatantly focused on marriage as the problem-solver and the ending of each (seemingly) happy novel. Gilbert and Gubar also talk about this subject at length, and say, "The implication is clear: marriage is crucial because it is the only accessible form of self-definition for girls in her society. Indeed, Austen's silence on all other subjects becomes itself a kind of statement, for the absences in her fiction prove how deficient are the lives of girls and women, even as they testify to her own deprivation as a woman writer" (127). The marriage plot as the primary focus of each Austen novel speaks to the 
limitations of women in Austen's society. Women could accomplish little more than to marry well. The marriage plot, which has always been viewed as a weakness, becomes the very strength of Austen's work. It shows the harsh reality that young women had to face and come to terms with. With this realization of Austen's strength as a writer, she may just be more of a realistic than romantic writer after all.

Of course, this only partially answers the question of why we continue to read Jane Austen. From a feminist point of view the value of Austen's work, especially coming from the Regency era, has been made clear. Austen wrote about the harsh realities of what she knew and exposed the struggle of being a woman with a limited education, and all of this remains valuable to understand and acknowledge. However, this does not answer to the very real, and at times strange, culture of Jane Austen readers that have an insatiable interest in all things Austen. No study of Austen can be complete without looking inward and thinking critically about the ways in which our culture engages with Jane Austen today. 


\section{Dull Eyes}

“to be so easily seen through, I am afraid, is pitiful." - Jane Austen, Pride and Prejudice

Mr. Darcy throws this comment at Elizabeth after she teasingly describes his character. Darcy's response is usually a comment glanced over and not deeply thought of. However, what Mr. Darcy casually says here points to a reality in their culture of trying to play a certain role to such an extent that any sign of transparency is almost shameful. Mr. Darcy does not want his true feelings to show, especially in such a public place like the drawing room. None of the characters want to be seen through. What the reader sees and interprets becomes so important because so rarely do the characters and narrator say what they mean. A first, second and even third reading of Pride and Prejudice all offer such vastly different details to the reader. What the reader notices and chooses to focus on becomes a sort of story in itself. From the opening line to the narrative technique and character development, there is so much to focus on when it comes to interpreting Jane Austen. Therefore, it is interesting to think about what we see in the novels, and what the adaptations willfully choose to not see. Thinking about how the culture's perception of Jane Austen changes the way we see the novels becomes the major focus of Dull Eyes.

The dull, glassy eyes of Austen's portrait seem to look nowhere in particular. They do not pierce through the admirer of the sketch, but purposely look away. The eyes completely avoid contact and almost seem to look inward. The admirer should begin to mimic this practice and do the same. What does it mean to read Jane Austen, and what exactly does this engagement with the novels do for the reader? How do films, spin-offs 
and other adaptations affect this reading? Jane Austen has become much more than an author with six novels, and instead a cultural icon with countless and constant reimaginings of her work. For this reason, it has become important to think about all things Austen, and what the new ways in which she surfaces says about the values of our society.

Jane Austen culture is no recent phenomenon. Readers have always been very passionate about the novels and all things surrounding them. Claudia Johnson's text Jane Austen's Cults and Cultures focuses on precisely this and discusses the history of Jane Austen's passionate readers. One of the very first things discussed in the text, and one of the most interesting, would be the close look at the evolution of Jane Austen's portrait. The analysis begins with the original sketch of Jane Austen (as shown on page 4) and over time so much of the portrait has been edited and enhanced to better suit the image Janeites have of Jane Austen. This is interesting not only because people have taken liberties to create the Jane Austen of their imagination, but also because everyone has strong opinions of what images should be embraced and which ones should be thrown away. The image of an author has never been so hotly debated. Much like the current situation with the bank note, the public can hardly decide whether they want a likeness of Jane that resembles Cassandra's sketch, or a softer and more attractive representation of the authoress. Jane Austen, through her novels, feels almost like a friend to her readers, and everyone has their own expectations of what she was like and what she should look like. Readers expect so much from the portrait of their favorite writer, and no version of her is ever universally accurate enough. Johnson eventually arrives at a final image, a sketch drawn by Cassandra Austen of Jane's back. Nothing shows but the back of Jane, 
standing in a field. It could literally be anyone. At this image, Johnson writes, "Jane Austen finally reaches us, much as the celebrated irony of her writing does, only in the act of turning away" (66). This sketch that shows little more than a silhouette, turns out to be the most accurate and indisputable likeness of Jane Austen.

Claudia Johnson goes on to discuss Austen's fame in the Victorian Era, World War I, World War II and finally on the Jane Austen home/museum. Johnson's research stops right before the flood of film and television adaptations come about. What Jane Austen's Cults and Cultures proves, more than anything else, is the adaptability of Jane. No matter what devastation the world was going through, namely the World Wars, Austen became a sort of sanctuary for soldiers to escape their chaotic world. Austen's portrait continually changes because her use in society changes as well. Austen may be a form of distraction for a soldier, comfort for a young woman, frustration for a student and entertainment for a filmgoer. Regardless of Austen's use, she always reappears in new ways and adapts to changing times. Johnson writes at the very end of her book, "Jane Austen's celebrity today is categorically different from the sorts of renown I have traced here in that it is so commonly mediated through screen adaptations. And if this remains the case, Janeism in the future will be a different thing" (183). Jane Austen never stops evolving because our culture will always need her in new ways. The Jane on film currently takes center stage in Austen culture. 


\section{The Adaptation}

"Mrs. Gardiner, looking at the picture; 'it is a handsome face. But, Lizzy, you can tell us whether it is like or not."' - Jane Austen, Pride and Prejudice

When the Gardiners and Elizabeth stumble upon Mr. Darcy's portrait during their tour of Pemberley, Mrs. Gardiner looks to her niece to see if the picture matches its subject. Elizabeth must look at the portrait and decide whether or not it looks like the Mr. Darcy she knows. Any representation can so easily stray from the real thing. For example, the banknote featuring Jane Austen looks almost nothing like the portrait in the National Portrait Gallery, and one can only imagine the differences between that portrait and the real person. In much the same way, constant reproductions of Austen's novels come along every few years, with each one so different from the last. Sometimes the adaptation can have so little to do with the original text that it is almost unrecognizable as an Austen adaptation. This, of course, is the major criticism with any adaptation of any novel. Critics will always say that the screen version does not faithfully follow the original text. With the Jane Austen films this is no exception. Many Jane Austen readers reject the film versions of Austen. However, this is hardly useful because the films have inevitably become such a huge part of Jane Austen culture. So many films and television series have been created from the 1990's to current day and in so many cases, a person's first exposure to Jane happens on the big screen before the written text.

In the article, "Janeites for a New Millennium: The Modernisation of Jane Austen on Film," Steenkamp Elzette discusses the modern film adaptations. Elzette writes, 
"These many cinematic adaptations have given rise to a new type of Janeite: modern-day women (and undoubtedly a fair number of men) who identify with Austen's heroines as depicted on film and may even consider themselves admirers of Jane Austen, but do not necessarily read Austen" (1). Jane Austen fans no longer have to read the novels to love the stories. Therefore, it is important to look at Austen adaptations in order to understand the appeal of Jane Austen without her writing.

Pride and Prejudice itself has had many adaptations with completely varying approaches, such as the $1995 \mathrm{BBC}$ miniseries or the modern film imagining of Bridget Jones's Diary (2001). So much can be said about every single version of the beloved novel, but a focus on the most recent film adaptation, the 2005 version starring Keira Knightley as Elizabeth Bennet, should say something about what modern viewers seem to want from an Austen adaptation. Although beautifully done from a visual point of view, the most interesting parts of the film come from the choices of the filmmakers to stray from the novel. Some key moments, especially the ones between Elizabeth and Mr. Darcy, have been altered to better suit a modern audience.

The first thing that comes to mind when thinking of major changes between film and text would be Mr. Darcy's first proposal to Elizabeth. In the novel, Mr. Darcy visits Elizabeth when she is alone at the Collins' residence and he begins his avowal of reluctant love with the words, "In vain have I struggled" (188). The moment turns into an argument with Elizabeth listing all the reasons for her to refuse his proposal and accusing Darcy of being un-gentlemanlike. Mr. Darcy finally storms out and many changes happen before he ever renews his offer of marriage. The scene is not a romantic one, and as a 
reader it is nice to see Elizabeth stand her ground and refuse an important man like $\mathrm{Mr}$. Darcy rather than give in when he has done nothing to deserve her affection.

The film, however, takes a very different approach to this scene. Instead of sitting in a drawing room, Elizabeth and Darcy are standing outside in the pouring rain. This much better fits the convention of modern romantic films, because almost every single time a couple gets together they are in the rain ${ }^{9}$. Mr. Darcy and Elizabeth start out speaking with fake civility but it does not take long for them to begin shouting at one another. The entire encounter is meant to be an argument but it looks much more like a lover's quarrel as they slowly move closer to one another until finally at the one hour and twelve minute mark of the film they are literally inches away from each other. It almost looks like Darcy is about to kiss Elizabeth but then thinks better of it and walks away. The words that they say so angrily do not match the body language of the film scene, and this is definitely an interesting choice made by the filmmakers. The film tells viewers at this point that Elizabeth and Darcy love each other; they just do not know it yet. The film has many more scenes of sexual tension building up between the two lead actors until they finally get together at the very end of the film.

The scenes in this film have all been completely manipulated to create a love story when the scenes could have just as easily been manipulated to tell a story about women trying to survive in a world where they have no autonomy. This is important to think about because what we have follows a much more romantic reading of Pride and Prejudice rather than a feminist reading. This says a lot about what modern audiences

\footnotetext{
${ }^{9}$ Many romantic comedies and dramas use the convention of the couple meeting in the rain, the most famous of which being The Notebook (2004).
} 
want to see in a Jane Austen film, and it surely does not match the more critical and feminist reading of the novel. Pride and Prejudice does not always have to be a love story and not many filmmakers have caught on to that idea just yet. Elzette also writes in "Janeites for a New Millennium," that "in order to satisfy a twentieth century audience... Austen's women must be submitted to a process of modernisation. They must be more fiercely independent, more active, and must challenge their male suitors more passionately" (4). Many Austen film adaptations have not necessarily caught on to this idea just yet. Elzette seems to believe that the 2005 Pride and Prejudice appeals to modern audiences by showing a scene between Charlotte and Elizabeth when she explains her decision to marry Mr. Collins because she is 27 and a burden to her parents (6). This scene certainly does shed light on Charlotte's struggle and it shows a different side to marriage, but the strength of it is almost cancelled when later on in the film audiences see Charlotte smiling and looking attentively as her husband fumbles through his sermon at church, one hour and six minutes into the film. In this moment Charlotte falls back into the category of a silly character and little more is said of her.

Film adaptations of Austen's work have become lazy and predictable. Audiences have seen the traditional versions of Pride and Prejudice and Mansfield Park. Everyone knows how the story has been told on screen. The novels leave so much space and possibility for the filmmaker to think outside the box. For example, the Charlotte Lucas character in the 2005 film was described by Elzette as a character that pushes boundaries by exposing her own harsh reasons for needing to get married. The opportunity with a character like Charlotte Lucas, however, has never been fully explored. As stated before, Charlotte has one strong moment before falling back into the category of a silly character. 
Why not think of a way to tell Charlotte's story more fully? Filmmakers have more opportunity to push boundaries and imagine Charlotte's world and her own narration of Pride and Prejudice. Audiences have seen Darcy and Elizabeth fall in love so many times, but no one has ever really explored Charlotte's daily life and her own struggles in a patriarchal society. Not only would a totally different reading of Austen be interesting for avid Jane Austen readers, but it would also force viewers to look at the original text since they no longer know the general plot of the novel the way they would with a traditional film version. Filmmakers should at least begin to explore totally different possibilities with Jane Austen. This would, inevitably, bring the academic and cultural circles closer together.

It is not merely film adaptations that oversimplify Austen's work as romance novels. Chick-lit spin offs, such as Austenland (2007) and Eligible (2016) recreate the plot of Pride and Prejudice but make sure to cut out all the elements that make the novel so complicated and worth re-reading. While Austenland completely simplifies Pride and Prejudice and quite literally places the protagonist at a sort of Jane Austen summer camp complete with all the bizarre costumes and modern woman trying to live in the Regency Era, Eligible tries a little harder by at least placing the family home at threat of foreclosure. Unfortunately, it still follows the same old modes of aiming for humor and romance without ever showing audiences a new and compelling way to talk about Austen. To be sure, these adaptations can be a fun and new way to engage with Jane Austen. However, it is important to see the harm in these far too simple recreations because they do not force the audience to ever think critically about Austen's work and it totally ignores the significance of what she wrote. Especially in most recent years, 
feminism has come much too far to ever accept these outdated and basic modes of reading Jane Austen.

In the academic article, "Post-feminist Austen," author Vivien Jones specifically looks at Jane Austen in relation to "chick-lit." Many novels and films use Austen as source material and Jones attempts to figure out the relationship between the two. Jones makes the argument that the Austen adaptations that have been created more recently speak to the "messiness" and "inclusive" nature of the feminism of today. Jones says, The best - and not just the best - adaptations and appropriations of classic texts invite us to read their originals afresh. In the case of chick-lit and its 'taking into accountness', reading back to Austen helps us adjust, I think, the still strong critical desire to appropriate her unproblematically for feminism, and to understand the post-feminist mechanisms which help make her novels such powerful examples of conservative writing. (79)

Austen will continue to be adored and continue to be recreated if past patterns continue into the future. The question now should be one of how exactly readers of Austen should move forward. How does one continue to mold Austen and still pay respect to feminism and other societal advancements? What should a modern reading of Jane Austen look like? 


\section{Moving Forward}

"Till this moment, I never knew myself." - Jane Austen, Pride and Prejudice

Upon reading Mr. Darcy's letter, Elizabeth is embarrassed to find that she has been wrong in her judgment. She did not see things from a different perspective and Elizabeth is shocked to find that she did not recognize her own shortcomings and blindness. This moment in the novel is important because it exposes Elizabeth, and shows that her point of view may not have been the most righteous and it becomes important for the reader to look back at the novel and begin re-reading to detect where things may have been misinterpreted. In much the same way, the reader will find that they as well did not "know themselves" and there can be many different and valid readings of Pride and Prejudice. Jane Austen can and should be much more than what the reader detects the first time around.

Discussing Jane Austen does not have to be the same, circular exercise of trying to prove that Austen should be included in discussions of "the greats" or that her work remains "important." Regardless of whether or not someone agrees with these statements is not nearly as important as thinking about new ways to read Jane Austen's work. Jane Austen has been so widely read and consumed that one can safely assume that this will not change any time soon. At this point the audience needs a compelling new way to interact with Jane. Lazy adaptations will not satisfy in the same way a totally different critical reading will. One of the most interesting interpretations of Jane Austen's work manages to change the way we talk about the novels and D.A. Miller calls it Jane Austen 
or The Secret of Style. Unlike many other critical pieces, Miller decides to pick up on the nuances of Austen's writing in order to make a point about the hidden style in her work.

Style, according to Miller's text, shows up when least expected. Style is when Austen addresses her audience, or when the plot surprises readers. Style can appear in Robert Ferrars' complete ignoring of the Dashwood sisters ${ }^{10}$, or in the mannerisms of the Austen heroine. Style is all over the Austen novel. Miller raises so many fascinating points in the text, but one that stands out discusses Elizabeth Bennet's use of style to get out of her situation in her family home. She must find a way to distance herself from a world she finds so dull and people she finds so embarrassing. Miller writes, What Elizabeth calls her "impertinence," and we her wit, draws the chief of its energies from a plainly visible psychic process of denial, the denial of everything in her vulgar, dysfunctional family and its imperiled economic position, that makes her situation needful, awkward, embarrassing, humiliating, even outright abusive. And this denial also serves as the principal tool, however unconsciously Elizabeth uses it as such, of a social ambition whose object is the only one allowed to women in Austen: marrying up. (43)

Miller does not try to glorify Elizabeth Bennet's intentions, like so many others have done. Just like the opening line of Pride and Prejudice spells out, Elizabeth Bennet wants and needs to "marry up." This does not make her a bad person, but a real person. As stated earlier, women do not have many options outside of marriage, and so they must try to marry well at the very least. Moreover, this does not make Jane Austen the writer a

\footnotetext{
${ }^{10}$ See pages 9-19 of Miller's text with a lengthy discussion of Robert Ferrars "broad stares" at the Dashwood sisters and not showing them any interest. This instance of style helps lead up to the surprise at the end, when he does marry Miss Steele.
} 
closed minded and ignorant person for having her heroines marry men "of good fortune," but rather an individual on a mission to open up discussions about the limited options available to women (5).

Miller goes on to discuss Elizabeth Bennet and uses multiple examples of Elizabeth's sly remarks to Darcy, most especially the moments when she pays him little to no attention. Elizabeth does not seem to try to win Darcy's attention, but naturally, she does. Miller says that a heroine uses style to get married, "provided only that she persuade herself into believing she is not using it to that end, or to any end but its own" (45). In the novel, Elizabeth makes it clear that she would never sacrifice happiness in order to be in an advantageous marriage. When Mr. Darcy proposes to her the first time, Elizabeth quickly shoots him down despite the obvious benefits that would come with such a union. Style has convinced Elizabeth that marriage is not necessarily important, or at the very least, that she is not actively seeking a partner.

Despite all this, style leads Elizabeth Bennet right into the arms of Mr. Darcy and she is happy to be there. It is at this point in the Austen novel that the heroine lets go of style completely. Once the Austen heroine finds love, she "is curiously eager to give up style, and without regret or remorse at having done so" (46). Style is so easy to let go of because it is a heavy burden for the heroine to carry around, to be always charming and witty. The constant performance can finally be put to an end once the heroine has secured her future. Once the performance is over, the heroine can be a normal person, with faults and insecurities, and embrace all those things instead of constantly trying to put on a face.

Miller's discussion of style in relation to the heroine is important because it directly addresses the marriage plot, issues surrounding the economics of these women 
and the ambiguity of Austen's writing style all at once. The discussion of style does a good job of opening up a new discussion about Austen's work without compromising what has been said before. In a world where so much has been written about Jane Austen and her work, Miller's text comes as a breath of fresh air.

Moving forward with Jane Austen, and knowing exactly how to do that, can be just as important as examining what has already been said. Audiences are ready to see a new side of Jane Austen. It is high time to began to think about the very real issues these characters face, simply because they are women, and not ignore all of it in the name of creating another romance film. The overly simple and sappy romantic route has been taken far too many times. If time has taught us anything, it is that Austen changes and becomes whatever we need her to be. Devony Looser says in The Making of Jane Austen, "She has adapted, or rather, many of us have adapted her, finding in her what best suits us. Her reputation has shifted with the times and with the needs and desires of her multiple audiences" (217). This means that we must shift as well, and force ourselves to think critically when engaging with Jane Austen culture. We must know ourselves as an audience, and know that we can do better. 


\section{Conclusion}

"The Bennets were speedily pronounced to be the luckiest family in the world; though only a few weeks before, when Lydia has first run away, they had been generally proved to be marked out for misfortune" - Jane Austen, Pride and Prejudice

Towards the end of the novel, the narrator laughingly points to the fickle nature of neighbors' gossip, and how the perception of one family can so rapidly change from day to day. The Bennets quickly rise in ranks as their two eldest daughters find good, marriageable men. It is through this very gossip and discussion that the Bennets change so dramatically, and it almost feels as if it is gossip that drives the plot of the novel. In some ways, the discussion surrounding Austen's work both in academia and within society in general almost resembles the town gossip in Pride and Prejudice. The novel can be perceived in so many different ways, and it has everything to do with the discussion that happens in classrooms and on screens. The academic and cultural spheres work together to keep an ongoing discussion of Pride and Prejudice alive. The novel cannot exist and continue to thrive without these discussions. So far, a lot of the perception of Jane Austen has been so focused on the marriage plot and the supposed love story, but just like neighborhood gossip, the discussion can take a turn at any possible moment.

What Jane Austen did was write novels that changed the way the world thought of women in literature, and that is no small feat. The novels not only offer endless ways to read and understand the situation of women, but endless ways to think of Jane Austen's 
writing. Jane Austen died so many years ago, but she has truly left behind a legacy that transcends literary studies and makes its way into popular culture. In "Imagining Jane Austen,” Anna Quindlen writes about Austen's gravestone, which has become an important monument for many Janeites. Ironically, the gravestone makes no mention of Jane as an authoress, but instead describes her as a daughter and sister. The monument willfully looks away from Austen's achievements, but somehow in doing so sheds more light on her unstoppable success as a writer. Quindlen says,

Luckily, that gravestone is not really Jane Austen's monument at all, but a monument to what people once thought-- sometimes, I think, what they still thinkshould be said of a woman. Jane Austen's real monument is in our hands, on our shelves, even on our e-readers. When I was young I needed to know that women could have lives, lives of purpose, of adventure, of daring, of achievement. And then a librarian handed me Jane Austen. And I learned that some women could live forever. (24)

Jane Austen, at the end of the day, will always be most powerful and most loved in her most pure form: through her books. It is not important to know who Jane Austen was, what she looked like, or what was written on her tombstone. It is only important to read and re-read her work and to think critically about how we go about it. The plethora of things that have already been said about Austen are important, but even more important are the things that remain unsaid.

Feminism enriches the reading of Austen's novels, and it could also help inform the adaptations that will inevitably keep being produced. There is no reason why academics should not influence the way popular culture consumes Austen, and vice 
versa. The intersection between academic and popular readings of Austen should be thought about more. The Making of Jane Austen says,

We've been too focused on repeating and engaging with the words and ideas of our own academic networks--our heroes and nemeses--or on quoting the ideas espoused by our mentors or our mentors' mentors. We've been too little focused on how the specifics of the Austen popular and commercial have intertwined with the Austen critical and scholarly, whether in conflict with each other, oblivious to each other, or in tandem. (218)

With such a world-famous author like Jane Austen, it becomes necessary to understand how she operates both within academia and popular culture. The separation of the two is not useful, nor does it make changes about the way we consume Austen. In order to live in a world where we see Charlotte Lucas spin-offs as opposed to strange Regency costume stories (Austenland), the two sectors must come together. We read Austen in the twenty-first century because we hungrily want more. We want to see something that will change the way we understand Austen and understand ourselves reading Austen. The world is ready for a new, smart way to move forward with Jane. 


\section{References}

Austen, Cassandra. Jane Austen. c. 1810, pencil and watercolour, National Portrait Gallery, London.

Austen, Jane. Pride and Prejudice. New York: Barnes \& Noble Books, 2003. Print.

---. Persuasion. New York: Barnes \& Noble Books, 2003. Print.

Barkley, Danielle. "Exit Strategies: Jane Austen, Marriage, and Familial Escape." Persuasions: The Jane Austen Journal, no. 37, 2015, pp. 214-222.

Brown, Lloyd W. "Jane Austen and the Feminist Tradition." Nineteenth-Century Fiction, vol. 28 , no. 3, Dec. 1973 , pp. 321-338

Christie, Sophie. "New $£ 10$ note featuring Jane Austen enters circulation today: everything you need to know." The Telegraph, 14 September 2017, www.telegraph.co.uk/money/consumer-affairs/new-10-note-featuring-janelausten-enters-circulation-today-everything/

Elzette, Steenkamp. "Janeites for a New Millennium: The Modernisation of Jane Austen on Film.” Transnational Literature, vol. 1, no. 2, May 2009, pp. 1-9.

Gilbert, Sandra M., and Susan Gubar. The Madwoman in the Attic: The Woman Writer and the Nineteenth-Century Literary Imagination. New Haven: Yale University Press, 1979. Print.

Hale, Shannon. Austenland. London: Bloomsbury Publishing, 2007. Print.

Johnson, Claudia L. Jane Austen's Cults and Cultures. Chicago: The University of Chicago Press, 2012. Print.

Jones, Vivien. “Post-feminist Austen.” Critical Quarterly, vol. 52, no. 4, Dec. 2010, pp. 65-82.

Looser, Devoney. The Making of Jane Austen. Baltimore: Johns Hopkins University Press, 2017. Print.

Miller, D. A. Jane Austen or The Secret of Style. Princeton: Princeton University Press, 2003. Print.

Moe, Melina. “Charlotte and Elizabeth: Multiple Modernities in Jane Austen's Pride and Prejudice.” ELH, vol. 83, no. 4, Winter 2016, pp. 1075-1103. 
Pride \& Prejudice. Directed by Joe Wright, performances by Keira Knightley and Matthew Macfadyen, Focus Features, 2005.

Quindlen, Anna. "Imagining Jane Austen." Persuasions: The Jane Austen Journal, vol. 34, 2012, pp. 13-24.

Sittenfeld, Curtis. Eligible: A Novel. New York: Random House, 2017. Print. 